\title{
Innovation in vegetable seed production and the role of consumers in the organic and conventional babyleaf chains: The case of Denmark
}

\author{
Lise C. Deleuran ${ }^{1,2 *}$ \\ ${ }^{1}$ Department of Environmental, Social and Spatial Change, Roskilde University, Denmark. \\ ${ }^{2}$ Department of Genetics and Biotechnology, Faculty of Agricultural Sciences, Aarhus University, Denmark. \\ ${ }^{*}$ Corresponding author: lise.deleuran@agrsci.dk
}

\begin{abstract}
In this study, the focus is on babyleaf products and the potentials that an increased interest in these products might bring to vegetable seed growers. Case studies on babyleaf products illustrate how consumers perceive babyleaf products and which parameters they give preference to. In addition, aspects of preference for local vegetable products were investigated. The methodological approach has been in the form of two questionnaires presented to consumers in two different chain structures, an industrialized chain (linking actors from 'farm to fork') and an alternative chain where organic produce is delivered to the consumers' doorstep through a box-scheme concept. The participants in the surveys were selected to identify elements that potentially could be used as a spur in innovation and development of new products in the chain and not necessarily to indicate general consumer interests. The overall conclusions are a genuine interest in babyleaf products in both approached chains. In the industrialized chain, $89 \%$ of the respondents would like more products and subsequently new niches within seed production are likely to occur. In the alternative chain, $83 \%$ of the respondents were very content with the babyleaf product they had received. In addition, these consumers display a profound preference for local products. The paper proposes that seeds and the quality of the seeds play an important role in babyleaf production and should be viewed as, not just a raw material in the chain, but also as the initial step in the babyleaf chain. Dialog among the actors in the chain is essential to meet the consumer demands from both a conventional and an organic perspective. The role of organic seed in organic vegetable productions is discussed.
\end{abstract}

Key words: babyleaf products, consumer preferences, consumer roles in value chains, spinach seed production

\section{Introduction}

Impelled by a global increase in the use of baby spinach (Spinacia oleracea L.), the Danish spinach seed production area increased from 2000 ha in 1996 to approximately 6000 ha in $2006^{1}$. Spinach seed production is favored in Denmark due to temperate climatic conditions, sandy loam soils and not least the years of experience gathered by farmers, seed consultants and research ${ }^{2}$. The vegetable seed industry is increasingly globalized. Each of the world's seed production areas has its competitive advantages and in search of new types for babyleaf production additional seed niches have emerged. The spinach seed industry in Denmark is a worldwide stronghold with a market share of almost two-thirds of the world ${ }^{1}$. Thus, seed farmers in
Skagit County, Washington, USA, compete with farmers growing spinach seed in Denmark and cabbage seed in South Africa ${ }^{3}$.

Up to 15 million seeds per hectare are used in babyleaf production ${ }^{4}$. This is more than ten times the amount of seeds that are used for bunched spinach. This creates the need for an increased production of seeds of not only spinach, but also for other leafy vegetable types used in babyleaf production. Seed professionals welcome the babyleaf trend and seed growers and seed companies have significant interest in maintaining their respective lead positions within seed production. The Danish region of Zealand, producing approximately two-thirds of the vegetable seeds (besides spinach, various cabbage species and chrysanthemum are widely grown for seed production in the region), has 
invested in motivating growers and researchers in seeds. A high-quality vegetable transplant/product originates from a high-quality seed. However, the quality dimensions of seed have not been given much attention in the value chain literature. Seed is often regarded as a raw material or a production input and not as an integrated part of the chain $^{5}$.

The spinach seeds produced in Denmark are distributed worldwide to the traditional markets in Asia and to new strong babyspinach producers in southern Europe who already have highly industrialized supply chains which enable them to supply most of Europe with quality babyspinach and other babyleaf products. This production requires investments in harvest equipment and cooling facilities. Such investments can hardly be borne by small-scale producers alone.

In the Italian babyleaf production, focus is on a wellfunctioning and unbroken cold chain (temperaturecontrolled supply chain) directly from harvest to delivery ${ }^{6}$. Therefore, it is possible for Danish supermarkets to sell and market quality babyleaf products from countries such as, e.g., Italy and Spain to Danish consumers all year round. Paradoxically, multiple Danish spinach seeds take a detour of more than $2000 \mathrm{~km}$ to southern Europe to become a babyleaf product and then return to Danish supermarkets and the Danish consumers.

Leafy vegetables, particularly babyleaf salads, are largely favored by consumers ${ }^{6}$. In the USA alone, the consumption of spinach increased from approximately $0.5 \mathrm{~kg}$ per capita in 1992 to approximately $1.0 \mathrm{~kg}$ per capita in $2008^{7}$. At present, no statistics on Danish consumption are available. Yet, in Denmark imports of spinach increased from 373 tons in 2000 to 2007 tons in $2006^{8}$.

In the USA, outbreaks of Escherichia coli in 2006 were linked to spinach and cleared store shelves and resulted in reduced use of spinach ${ }^{9}$. The $E$. coli scare depressed use in the USA by approximately $20 \%$ in 2006 compared to $2005^{7}$. Subsequently, producers worried that consumers would lose confidence in the industry. Spinach consumption in the USA is forecasted to rebound to the 2005 level by 2010 .

In the Western world, babyleaf products have a quite strong appeal to consumers as they meet many needs for a modern trendy lifestyle. Consumers are concerned about the food they eat, and convenience is a factor that is increasingly important to them ${ }^{10}$. Further, it is widely anticipated that the demand for food-related convenience will continue to increase ${ }^{11}$. However, convenience is far from the only consumer preference. Many consumers favor organic products and/or local products. It is significant to acknowledge that there are current alternative interests among consumers than those related to highly specialized and industrialized supply chains ${ }^{12}$. Consumer concerns for food safety, animal welfare and the environmental and ecological impact of food production and agro-processing have become increasingly important. These concerns have been exacerbated by several factors, including the trend toward further globalization of the food supply chain ${ }^{5}$.

Seed quality has always been of great importance especially when producing vegetables. Seed quality is a broad term and encompasses several attributes of seeds including germination and seedling performance ${ }^{13}$. For the vegetable producers, low and/or uneven seed germination results in products of varying quality and, in worst cases, discarding of the produced lots. The quality dimensions of the seed are quite important in order to avoid, e.g., seedborne diseases and following blemished products. Today's increased interest for organic vegetables and the arising new market for babyleaf products have put even more emphasis on the quality of the produced seeds.

The seed genetics together with environment, management and technology define the final quality of the product. Greater vertical integration is seen as necessary to maintain quality throughout the 'life' of the product, explaining the emergence of terms such as 'seed to shelf', 'farm to fork' and 'plough to plate'14. In 2007, a large project on seed quality in vegetable chains was initiated in the region of Zealand in Denmark. During the project, different salad vegetables were tested for babyleaf production and test seed productions of these were evaluated.

This paper addresses current innovation possibilities, in the value chain that deals with seed for babyleaf production and babyleaf products. The analysis is based on the hypothesis that strengthening the innovation of babyleaf products is closely linked to how the actors in a value chain interact and communicate. In particular, feedback loops between the different actors, including consumers, are decisive for the innovative capacity for differentiation and initiation of new products.

Two separate surveys based on questionnaires were conducted to obtain feedback from consumers on preference for babyleaf products. The first survey included recipients of an organic 'Dogma' box and the second survey embraced consumers visiting an agricultural fair. None of the surveys are based on random sampling. The 'Dogma' box recipients have actively chosen to buy products of local origin. They received a specific babyleaf product in the Dogma box to reflect upon. The 'Agricultural Fair' consumers represent a group of consumers who actively seek out venues where food products are on display. They were provided samples of different kinds of babyleaf products for taste. The two distinct consumer groups were selected on the premise that they could be expected to have interests and preferences that might provide a productive spur for innovations in the babyleaf chains.

The main objective of the first study was to explore among organic 'Dogma' consumers their preference for quality and localized organic babyleaf products. The objective of the second study was to explore overall consumer interest in babyleaf products and, in addition, to obtain feedback on the seed source for leafy vegetable products. 


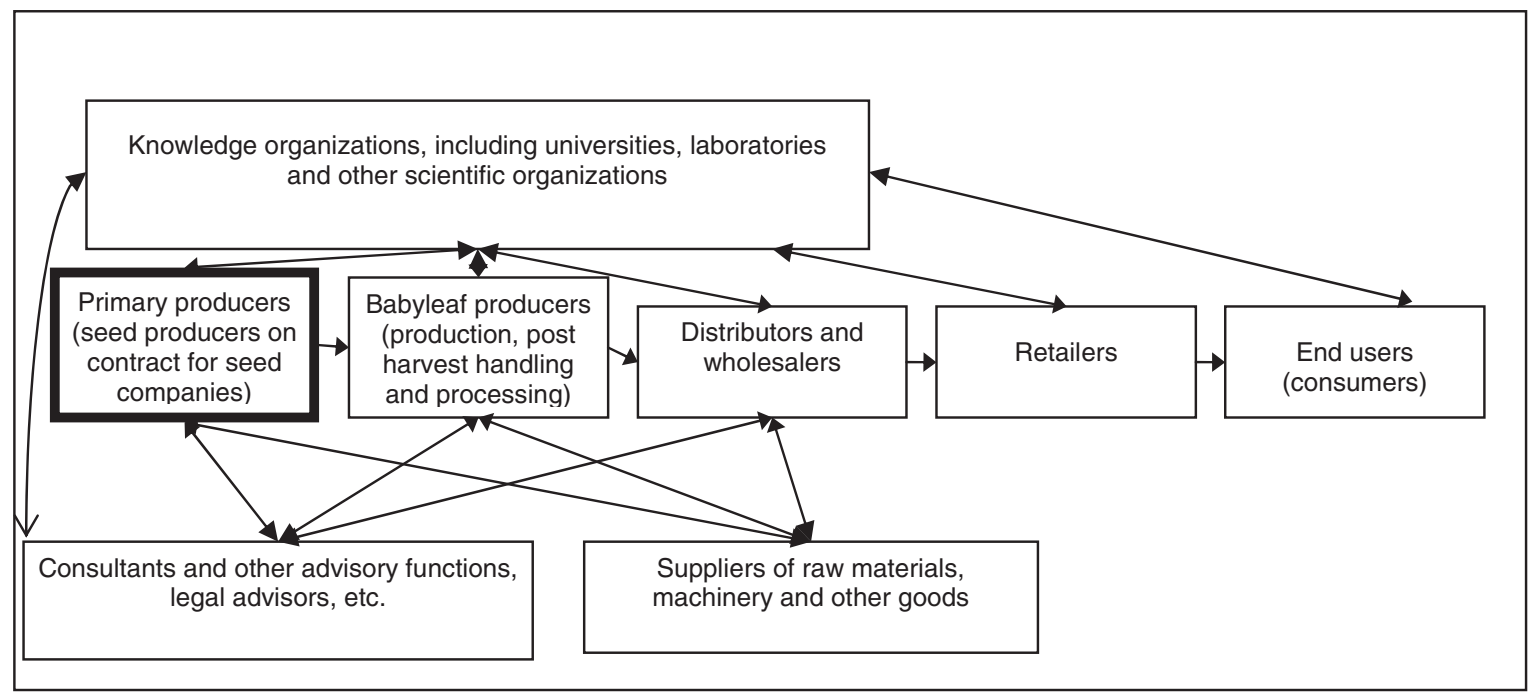

Figure 1. The babyleaf network modified from a supply chain perspective ${ }^{18}$.

\section{Conceptual Framework and Context for the Study}

In this study, two types of babyleaf chains were analyzed. The first type was the highly industrialized chain characterized by babyleaf products from multiple suppliers in various countries, distributed to different retailers and subsequently bought by consumers. The second type was an alternative chain based on organic produce where the same company produces the babyleaf products and following packs and delivers directly to the consumers. Analysis of these babyleaf chains was based on the literature regarding supply chain studies ${ }^{15,16}$. A supply chain exists when different actors are linked from 'farm to fork' to achieve a more effective and consumer-oriented flow of products. It is this supply chain approach that raised the issue of consumers' interest in babyleaf products and the seeds used in the production. In the following the supply chain and the value chain concepts will, for simplicity, be integrated and mainly referred to as the babyleaf chain. The supply chain refers to downstream flow of goods and supplies from the source to the retailer and the value chain is flow in the opposite direction ${ }^{17}$.

It can be discussed where the chain begins and ends ${ }^{18}$. It might be argued that all chains commence with primary production. When it comes to innovation within vegetables most researches have focused on the part of the chain from food processing onwards. Various inputs to and processes in the chain are based on research and development. In the case of babyleaf produce, the primary production is the production of the seed that goes into the babyleaf production. Figure 1 is a graphical presentation of the babyleaf chain and its network as it is approached in this study. This constitutes the beginning of the chain, and subsequently value is added when the right kind of seed of the right quality is sown and turned into a babyleaf product and further processed and distributed to consumers ${ }^{1}$. The choice of seed both in terms of quality and genetics is of utmost importance for product quality. This is the determinant for resistance against diseases, taste and other parameters appreciated by the consumers following appropriate agricultural practices.

Actors who take an active part in the core processes within the chain are seen as core actors in the babyleaf chain. Consultants providing the core actors with sectorspecific knowledge, knowledge institutions developing and disseminating specialized new knowledge, educational institutions supplying a trained workforce and suppliers of raw materials (e.g., fertilizers), machinery and other goods contribute to value and knowledge generation within the chain $^{18}$. As Figure 2 illustrates, a direct feedback loop from the end users to not only retailers but also the whole chain is proposed as this could be a driving force in innovation regarding new products, new mixtures and new uses of babyleaf products.

The system of innovation within babyleaf production is a spring-off from the traditional value chain approach. Primary raw material in the chain from soil to table is manufactured and thereby a value-added effect is seen. While these processes are ongoing, both formal and informal knowledge sharing takes place among the chain core actors. This also includes interaction between the food sector and other actors such as research institutions. Innovation covers not only aspects of radical nature, such as totally new products and processes, but also gradual innovations that typically relate to small adjustments and further developments of products and ongoing processes ${ }^{19}$.

\section{The babyleaf spinach chain}

Babyleaf is a new type of product within the vegetable assortment. The interest in babyleaf products has spread from the USA and New Zealand to Europe and is now rapidly spreading to the rest of the world. At present, it is 


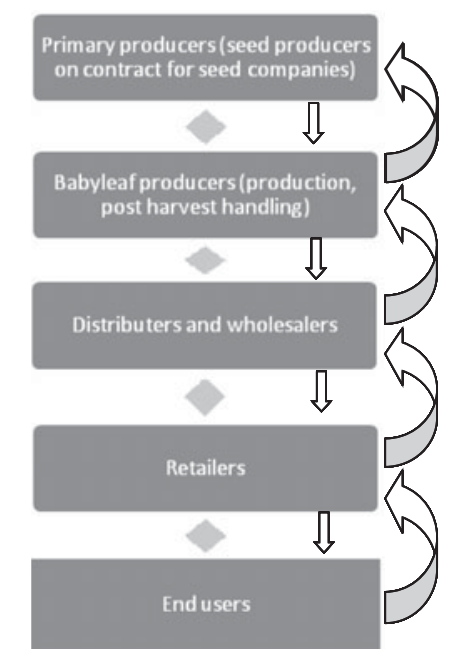

1. The core actors in the babyleaf chain. Most interaction in the chain is one link back and forth.

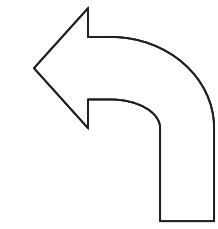

Attached research and knowledge institutions, consultants, etc.

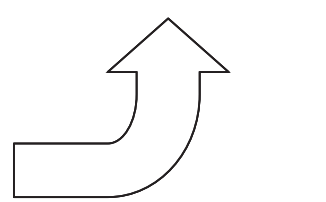

2. Proposed feedback loops in the chain from end users (consumers) either directly or through attached knowledge institutions, etc. Illustrated by open arrows.

Figure 2. The babyleaf chain and proposed interactions in the chain and feedback loops.

finding its way into the Chinese market, yet mainly as a tourism product and high-grade vegetable ${ }^{20}$. In the USA, one of the fastest-growing segments is prewashed babyspinach $^{21}$. As such, it is a convenient product, ready to use, fitting perfectly into the modern consumers' request for semi-prepared foods. Spinach is now one of the most popular babyleaf products and is considered the most or second-most nutritious vegetable consumed in the $\mathrm{USA}^{22}$. Spinach leaves contain relatively high levels of bioactive compounds such as vitamin $\mathrm{C}$, vitamin $\mathrm{A}$ and minerals ${ }^{23}$.

Numerous indicators supporting the growing babyleaf market can be found: there is an increasing supply of different kinds of seeds for babyleaf production; shelf meters in supermarkets are growing; products such as mixed babyleaf, rucola and spinach are today stable in most supermarkets and even in discount stores; gourmet restaurants serve babyleaf products; new recipes contain babyleaf products and in addition organic babyleaf products are now slowly entering the market. Unfortunately, no separate statistics on babyleaf products can be found in Denmark and exact figures from supermarkets are not accessible.

Spinach is an annual cool-season crop, and in coastal temperate areas with mild winters it can be grown all year round ${ }^{24}$. A seed such as spinach germinates at temperatures 2 to $30^{\circ} \mathrm{C}$, grows at 5 to $24^{\circ} \mathrm{C}$ and can withstand some frost $^{25}$. In a mild year it is possible to grow babyleaf spinach almost all year round in Denmark, and thereby supply the consumers with local fresh produce. Yet, research has shown seasonal influences to affect the quality of baby spinach leaves ${ }^{24}$. During some periods of the year Danish babyleaf products might not be of the quality consumers want.
To meet the growing demands even in the peak Danish growing season, babyleaf products from southern parts of Europe have entered the market, illustrating the international division of labor throughout the chain.

\section{An alternative food chain}

Regarding organic vegetables, the Danish company Aarstiderne.com runs a successful internet-based box scheme concept and delivers weekly boxes of organic fruit, vegetables, meat, fish and bread to Danish families. This is a company that has succeeded with local products and they provide an alternative to the internationalized supply chains. They engage in a novel variant of face-to-face interaction through the internet as a mechanism for aligning producerconsumer networks, as described in Renting et al. ${ }^{26}$. The company itself is responsible for the production of most of the vegetable products that go into their boxes. They also pack and deliver the boxes to the doorsteps of their consumers. In addition, they deal directly with the consumers and therefore receive immediate feedback if something is wrong or missing in the box. In this way they are in charge of the chain for babyleaf production all the way to the consumer (Fig. 1). This short food supply network holds the potential for shifting food production out of its 'industrial mode' and breaking out of the long, complex and rationally organized industrial chains ${ }^{27}$. The concept is an important carrier for creating new and transparent linkages between agriculture and society, producers and consumers. The initiative by the Danish company brings consumers closer to the origin of their food by descriptions of both products and producers in newsletters that accompany the 
boxes and on their webpage. The consumers have the option to visit Aarstiderne.com facilities. These facilities offer farm shops and possibilities for social gatherings. This enables the consumer to establish connections with the place/space of production and, potentially, with the values of the people involved and the production methods employed. These successful methods of translation of information allow products to be differentiated from more anonymous commodities and command a premium price if the encoded information is considered valuable by consumers ${ }^{26}$.

A key characteristic of this type of supply chain is the capacity to re-socialize or re-spatialize food, thereby allowing the consumer to make new value judgments about the relative desirability of foods on the basis of their own knowledge, experience or perceived imagery. Commonly, these foods are defined by either the locality or even the specific farm where they are produced, and they serve to draw upon an image of the farm and/or region as a source of quality. Short food supply chains on the one hand 'shortcircuit' the long, anonymous supply chains characteristics of the industrial mode of food production ${ }^{27}$.

\section{Organic seeds}

In the organic vegetable production, organic seed is still not available in sufficient amounts ${ }^{28}$. Despite the organic regulations (Council Regulation (EEC) No. 2092/91 of 24 June 1991 on organic production of agricultural products), organic vegetable growers can still be granted dispensation to use non-organically grown seeds for some of their vegetable productions ${ }^{29-31}$. There continues to be difficulties for seed producers with equivalent production of organic and non-organic seeds of the same variety ${ }^{32}$. This leads to organic production of somewhat older varieties, meaning that many of the best new varieties do not reach the organic growers quickly enough ${ }^{29}$. Therefore, to secure wide variety and to allow for new cultivars and improvements of cultivars it might be necessary, to some extent, to allow for nonorganic seeds or in-conversion seed in organic productions. Yet, organic vegetable supply chains as a starting point should aim at using only organically produced seeds ${ }^{33}$.

Rubitschek $^{34}$ has defined different types of organic vegetable growers with different demand to the seed suppliers (with all modulations in between):

- Organic growers, who give priority to organic seed, including growers who are looking for long-term adapted varieties and growers who are looking for the most modern varieties.

- Organic growers, who give priority to genetic characteristics.

- Organic growers, who give priority to less expensive (conventional) seeds.

The latter group of growers feel that the price difference between organic and conventional seed is too large for their business. Hence, they avoid the obligation to use organic seed and specifically choose varieties where no organic seed is available. Consequently, they can use a less expensive conventional seed source.

Babyleaf products are harvested shortly after field germination and it is unknown whether the organic consumer is willing to accept babyleaf products based on conventional seed. For now we therefore assume that the organic consumers' main belief is that organic babyleaf products are based on organic seed.

Babyleaf production has some advantages that consumers might not be aware of. Due to the relatively short production cycle, these productions are not sprayed for pests and diseases. This is not allowed due to fixed waiting periods on agricultural products. This is the period prior to harvest where pesticides may not be applied, since simply washing the product will not remove the applied substance. Lupton's ${ }^{35}$ arguement is that the link between health and nature is 'constructed' because many fruits and vegetables, which seem totally natural, are grown using chemicals.

\section{Consumers' preferences}

It is assumed essential for consumers not only to buy convenience products, but also to buy a product that has been produced in a certain way. The subjective values are generated by the consumers' wish to buy products with special characteristics or which have been produced in a certain way; for example, organic production from organic seeds or conventional products without the use of genetically modified (GM) seeds. Yet, consumers differentiate in various ways between products and both objective and subjective values are, to a high degree, determined by the individual. A great challenge lies in understanding and decoding the subjective dimensions in order to make products that meet consumer demands or differentiate a product from a competing product.

Dietary debates in the Western world have revolved around the concept that nearly everything can be provided in a pill or capsule ${ }^{36}$. By contrast, the perception that foods themselves are beneficial and can provide much greater clinical and biochemical improvements to patients than pills is a relatively new finding. Clearly, the whole is better than individual components, that is, consumption of diets rich in antioxidants, such as green vegetables, is far better than taking a dietary antioxidant pill ${ }^{36}$. The consumers' interests and the way consumers decide to purchase vegetables is quite complex. Asking consumers in an openended interview what they regard as food products of good quality, the answers radiate around four central concepts: taste, health, convenience and naturalness ${ }^{37}$. Health is therefore among several dimensions of food quality in the mind of consumers. It follows that consumers can differ in the weighting of health compared to other quality dimensions such as taste, and that consumers may perceive tradeoffs between health properties of a food and other desired quality dimensions, notably taste and convenience. Intensive studies in babyleaf products have revealed quite desirable nutritious aspects of these products ${ }^{38-40}$ and more 
data are likely to be generated in the years to come. Whether this will affect consumer priorities is a different issue. Another feature is the concept of authenticity: consumers want their food to be trustworthy and produced with consideration for ethical values such as fairness in the supply chain and care for the environment ${ }^{41}$. Consumers' trust develops in the course of a long-term relation, following a form of learning process ${ }^{42}$. If consumer trust in a product is lost, as seen in the case of $E$. coli outbreak linked to spinach in the $\mathrm{USA}^{7}$, market shares might be very difficult to regain.

\section{Methods}

Two questionnaires for two diverse consumer groups have been developed. The first group comprised dedicated organic 'Dogma' consumers. This questionnaire was developed in cooperation with the Danish company Aarstiderne. com to extract consumer perceptions of babyleaf products among their customers. In addition, qualitative interviews were performed with the Head of Vegetable Production and the Organic Advisor at Aarstiderne.com to get more insight into the processes of their management of vegetable production. Aarstiderne.com runs a box scheme concept and delivers weekly boxes of organic fruit, vegetables, meat, fish and bread to 45,000 families in Denmark. They have also added Swedish consumers to the recipient list. About $70 \%$ of the food sold comes from Danish producers. This is done by selling through different subscriptions via the internet from the company webpage. This makes the supply chain very short, omitting middlemen. Aarstiderne.com has its own vegetable farming facility at Gram in Denmark, and has produced organic babyleaf products since 2006. Other organic vegetable farmers provide supplementary produce. The concept includes production of vegetable types which are relatively new- or old-type vegetables reintroduced to the Danish consumers, such as purslane. The interview with the Head of Vegetable Production at Aarstiderne.com revealed that the company maintains a closed organic cycle in its production whenever possible. Therefore, varieties of biodynamical or organically produced nature are chosen.

The questionnaire that was sent by Aarstiderne.com was followed up by a brief description including photos of the babyleaf product. The consumers had received the babyleaf product 1 week prior to the survey. The survey took place in December 2008, in order to produce a freshly harvested field babyleaf product out of the peak season. During winter, this box mainly included root vegetables and different kinds of cabbages. Presenting an 'out of season' product probably came as a surprise to some of the respondents. The chosen babyleaf product was cornsalad (Valerianella locusta), which can be grown and harvested during winter in Denmark.

The questionnaire was internet based and designed to take less than $5 \mathrm{~min}$ to complete. The questionnaire was sent to all 'Dogma' recipients who had received the babyleaf product $(N=444)$. In total, 213 responded to the questionnaire within $48 \mathrm{~h}$ ( $48 \%$ response rate). The response rate was evaluated by Aarstiderne.com and found to be within the normal range of what the company normally receives and on which it further evaluates its data. The second group of respondents were selected among a consumer group visiting an agricultural fair during June 5-7, 2009. The Roskilde 'Agricultural Fair' offered a chance to present various babyleaf products and to gather opinions and views from a mixed group of consumers. People attended the fair for several reasons, generally because of interest in farm animals, farm equipment, outdoor activities and market/fair shopping. In 2009, a large food exhibition was held on how to manufacture Danish agricultural products and the questionnaire was placed with the exhibition's stand 'From seed to salad'. Here, various sprouts and babyleaf products were exhibited together with the seeds that go into the production. The regional chef school-Selandia-prepared various salads with sprouts and babyleaf products (e.g., amaranth, komatsuna, red frills, rucola and spinach), for tasting and also recipes were handed out. In total, 112 took the time during the fair to fully complete the questionnaire. The questionnaire might have been too comprehensive as many (43) questionnaires were left only half answered. These were discarded from the survey. As the questionnaires were left unattended at the stand, visitors had to be active to participate in the survey. The consumers who did answer took the time and effort, despite the many priorities attached to a visit at an agricultural fair and must therefore be considered dedicated consumers. There is no reason to believe that the results would have been different if the 43 half-answered questionnaires had been completed. An estimate on how many people visited the stand 'From seed to babyleaf product' while the chef school prepared samples was 2300. This is based on how many recipes were handed out along with the babyleaf salads. It is likely that individuals visited the stand without taking a recipe.

More than $80 \%$ of the respondents to this second questionnaire were women and more than half resided in a countryside area. Twenty-eight percent of the respondents were from 16 to 29 years of age, $45 \%$ from 30 to 49 years of age and $27 \%$ of the respondents were above 50 years of age.

Both groups of respondents, prior to answering the questionnaires, had in different ways been exposed to babyleaf products. The respondent groups represented two different chain approaches and two different consumer groups as described above. The two groups were not identified as representatives of general consumer interests, but instead as groups of dedicated consumers who might possibly identify elements that could be used as a spur for innovation and development of new products or production concepts in the babyleaf chain.

\section{Statistics}

The collected data were summarized by descriptive statistics (SPSS 17.0; SPSS Inc., Chicago, Illinois, USA). The 
Table 1. 'Dogma' consumers' contentedness with the babyleaf product they received.

\begin{tabular}{lcccccc}
\hline Question & Very content & Content & $\begin{array}{c}\text { Either content } \\
\text { or discontent }\end{array}$ & $\begin{array}{c}\text { Less } \\
\text { content }\end{array}$ & Discontent & Comment \\
\hline Contentedness, babyleaf product & $38 \%(81)$ & $45 \%(95)$ & $8 \%(17)$ & $3 \%(6)$ & $1 \%(2)$ & $11 \%(23)$ \\
\hline
\end{tabular}

(a)

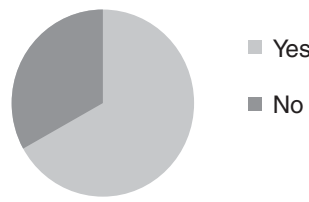

(b)

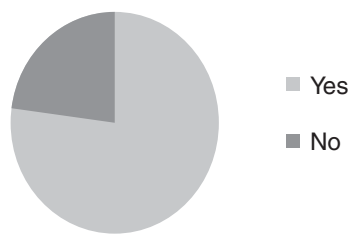

Figure 3. 'Dogma' (a) Consumers' interest in knowing who produces the babyleaf products and (b) preference for Aarstiderne.com's products. Results of an internet-based questionnaire at Aarstiderne.com, December 2008.

'Dogma' survey results are mainly presented by frequency figures. To analyze differences between consumers, the respondents in the agricultural fair survey were divided into three main groups: $16-29,30-49$ and above 50 years of age. The results were also divided into two groups based on the frequency of use of babyleaf products. The significance of differences between the groups was established using contingency (cross tabulation) tables and Pearsons chisquare (at the $5 \%$ level of significance).

\section{Findings}

\section{'Dogma'consumers-questionnaire I}

Table 1 lists the 'Dogma' consumers' contentedness with the received babyleaf product. Eighty-three percent of the respondents indicated that they were very content or content with the babyleaf product.

All respondents were asked to highlight their interest to know who produced the products and, as shown in Figure 3a, 67\% of the 'Dogma' consumers showed great interest in knowing who had produced the babyleaf product. The respondents answering 'Yes' were asked if they preferred the products produced by Aarstiderne.com. Here 74\% answered 'Yes' (Fig. 3b). As a follow-up, these respondents were asked to respond to where they prefer the origin of the products to be. The majority said they preferred Danish products (Fig. 4). Comments to these questions were all related to either climate $\left(\mathrm{CO}_{2}\right)$ or transport. Examples of these included "As a start the important is good quality and not origin, yet transport and $\mathrm{CO}_{2}$ also has great importance', 'Organic, good quality and with a production with low $\mathrm{CO}_{2}$ leakage', 'I do not care if the product is produced by Aarstiderne.com, but it makes sense that it is Danish produce', 'I prefer local and good', 'As short transportation as possible and good quality, then origin is not so important', 'I prefer products grown close by in a $\mathrm{CO}_{2}$ friendly manner', 'Always products with as little transport as possible (less $\mathrm{CO}_{2}$ )'.

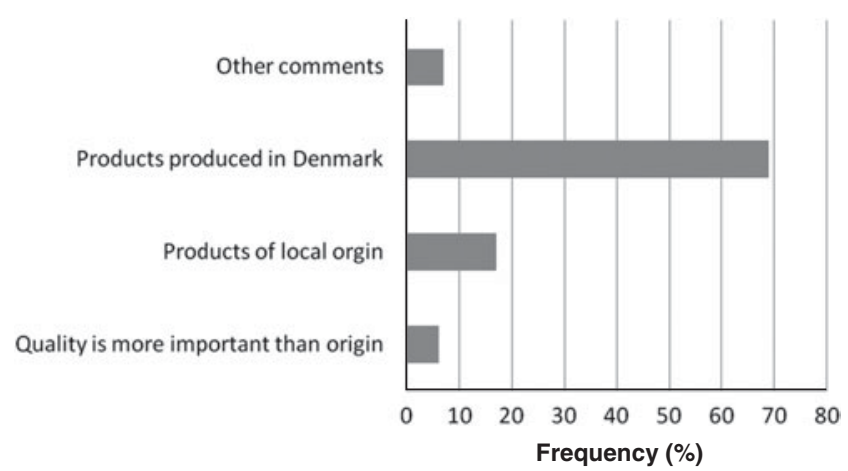

Figure 4. 'Dogma' consumers' response (\%) to questions of quality and origin of vegetable products. Results of an internetbased questionnaire at Aarstiderne.com, December 2008.

When asked if they were interested in consuming more babyleaf products, $42 \%$ answered 'Yes', 27\% 'Maybe' and $28 \%$ 'No'. There were significantly more respondents answering 'Yes' than 'No'. Eleven percent commented on the question, of which $6 \%$ answered that their main interest was babyleaf products in 'season'. The respondents had not been exposed to the fact that the babyleaf product they received was grown in the field. Therefore, many respondents highlighted concerns about how the product was produced (greenhouse with heating). The 42\% 'Yes' respondents were then confronted with statements regarding issues that would make them more interested in consuming babyleaf products. Most respondents (32\%) indicated a larger selection (Fig. 5). Little emphasis (8\%) was put on information of nutrients.

\section{Agricultural Fair consumers-questionnaire II}

As illustrated in Figure 6, most respondents thought that the babyleaf products were fresh and crispy and tasted better than traditional lettuce. However, appearance and convenience were also quite central parameters. Not much attention was paid to health issues related to the product.

The 'Agricultural Fair' respondents expressed profound interest in local products (Fig. 7a). Yet, when put into context with relations on appearance, country of origin, price and shelf life, the local parameter scored the lowest (Table 2). Under 'other preferences' $8 \%$ mentioned organic products.

The 'Agricultural Fair' consumers were asked how often babyleaf products were used in their household (Table 3) and were then divided into two groups. The first group represented frequent users (one or more times a week) and the second group represented less frequent users (once in a while or never). The frequent users select the babyleaf 


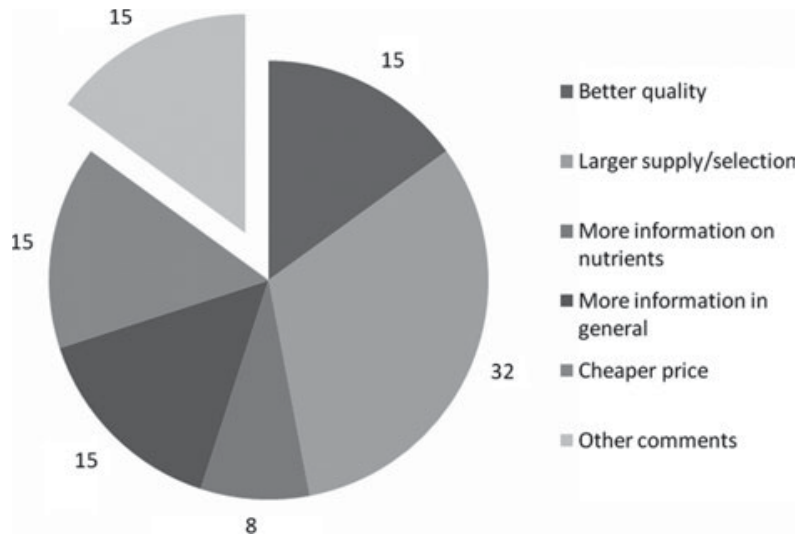

Figure 5. 'Dogma' consumers $(N=146)$ motivations to consume more babyleaf products. Results of an internet-based questionnaire at Aarstiderne.com, December 2008.

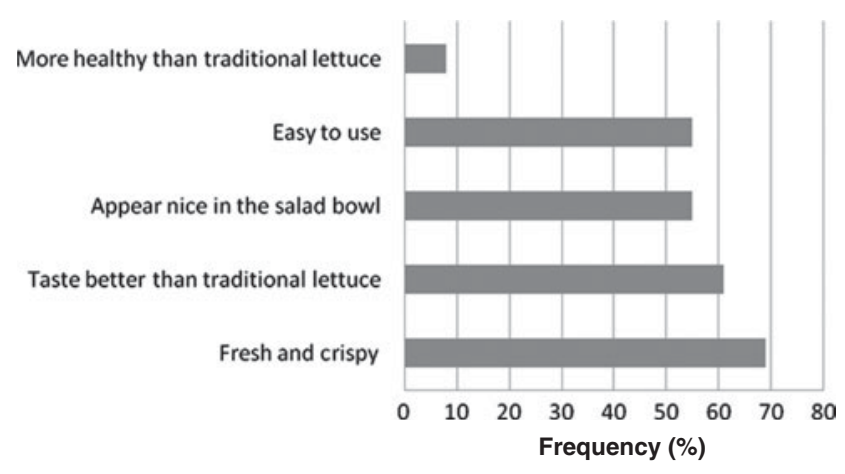

Figure 6. Frequency (\%) of 'Agricultural Fair' consumers response to yes/no/? questions regarding (a) preference for local produce, (b) preference for knowing seed source, (c) opinion on seed source for organic produce and (d) interest in more babyleaf products on the market. (a)

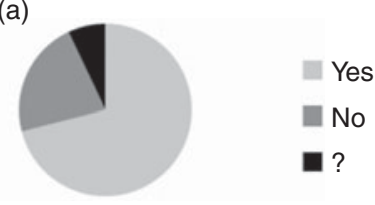

(c)

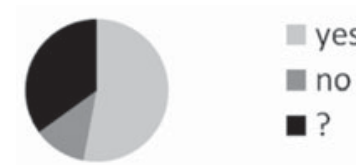

(b)

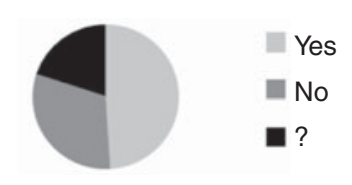

(d)

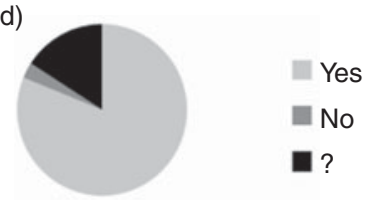

Figure 7. Frequency (\%) of 'Agricultural Fair' consumers response to yes/no/? questions regarding (a) preference for local produce, (b) preference for knowing seed source, (c) opinion on seed source for organic produce and (d) interest in more babyleaf products on the market.

products as they taste better than traditional salad $(P=0.018)$. This is the common answer from both female and male consumers. The younger group (16-29 years of age) looked more for product price than the older groups $(P=0.043)$.
Approximately half of those surveyed would have preferred to know the seed source that goes into vegetable production (Fig. 7b). More than half of the 'Agricultural Fair' consumers reflected that organic seeds are always used in organic vegetable productions; yet, more than $30 \%$ indicated a question mark on the matter (Fig. 7c). The last question referred to interest in more babyleaf products on the market (Fig. 7d). Here $89 \%$ indicated that they would like more products. The questionnaires included pictures of different babyleaf products (common sorrel, yellow and green purslane, and oak leaf lettuce) which at present are not available through the industrialized chains. All products, except for yellow purslane, had the respondents' interest as 48-59 respondents had ticked the box 'I would buy this product if available in supermarkets'.

\section{Discussion}

Babyleaf products possess attractive elements for the consumers such as freshness, taste, convenience and appearance. Still, many consumers are not aware of all benefits associated with the babyleaf products and in both the 'Dogma' and the 'Agricultural Fair' survey; only a few respondents highlighted nutrient content or health-related issues to be a driver to buy babyleaf products. In contrast, many surveys have documented an increased focus on health among consumers, which have led to an increased focus on: whether a food is healthy or not; how much fat it contains and what healthy properties it possesses ${ }^{12}$. This contradiction might be explained by consumers associate all fruits and vegetables with healthiness, but, with a few exceptions, they are unable to differentiate more nutritious items from less nutritious ones, as proposed by Shewfelt ${ }^{43}$. There are indications in the recent literature that babyleaf products encompass various health properties ${ }^{38-40}$. It is a production where no chemical fertilizers are allowed and the fast-growing babyleaf cultivars contain less oxalate than their slower-growing counterparts ${ }^{44}$. Whether this will affect consumer preferences is unknown.

The scene was somewhat preset when selecting a group of Aarstiderne.com consumers that subscribe to a 'Dogma' box. In winter that means a lot of roots, tubers and greenhouse lettuce. The Dogma box, which accounts for between $5 \%$ and $10 \%$ of Aarstiderne.com's orders, keeps the company on its toes by pushing it to discover the limits of what is possible to grow locally ${ }^{45}$. Thus, the 'Dogma' box subscribers seemed to have liked the variation the babyleaf product offered among the more coarse vegetables, as $83 \%$ of the respondents either were very content or content with the product. In addition, $42 \%$ thought 'Yes' to additional babyleaf products in the 'Dogma' box. Putting a babyleaf product in a 'Dogma' box could be considered the ultimate test for the preference for such a product. Most likely it challenged the organic consumers, beliefs on what could be grown in Denmark in December. Yet, the way they welcomed the innovative product indicates trust in Aarstiderne. com from the majority of the consumers. The respondents 
Table 2. 'Agricultural Fair' consumers' $(N=112)$ preferences $(\%$, it was possible to select more than one option) when purchasing vegetable products. Options: appearance; origin (country of production); price; shelf life and local products.

\begin{tabular}{|c|c|c|c|c|c|c|}
\hline Question & Appearance & $\begin{array}{c}\text { Origin } \\
\text { (country of production) }\end{array}$ & Price & $\begin{array}{l}\text { Shelf } \\
\text { life }\end{array}$ & $\begin{array}{c}\text { Local } \\
\text { products }\end{array}$ & $\begin{array}{c}\text { Other } \\
\text { preferences }\end{array}$ \\
\hline $\begin{array}{l}\text { What do you give preference to } \\
\text { when you buy vegetable products? }\end{array}$ & $86 \%$ & $66 \%$ & $58 \%$ & $50 \%$ & $44 \%$ & $8 \%$ \\
\hline
\end{tabular}

All comments refer to organic produce.

had not been informed that the babyleaf product they had received was grown in the field and therefore their concerns about how the product was produced were quite justifiable. Not surprisingly, $74 \%$ of the respondents preferred Aarstiderne.com's own produce. This indicates trust and commitment to the brand and proves that the 'Dogma' box is a deliberate purchase.

The Roskilde Agricultural Fair offered a chance to present various babyleaf products and get opinions and views from a mixture of consumers. People come to the fair for many reasons. The data indicate an overrepresentation of people from rural areas $(53 \%)$ compared to the average Danish population. This might be caused by the location of the Roskilde Fair and traditionally the display of many activities that attract people with farm and outdoor interests. By contrast many people from larger cities use the opportunity to expose themselves and their children to farm and outdoor activities. More than $80 \%$ of the respondents in the questionnaire were women. Similarly, these kinds of food exhibitions attract the female audience. Women are frequently responsible or co-responsible for shopping for food which often leads to a larger representation of women in various investigations of consumption patterns ${ }^{12}$.

When asked what parameters they look for in vegetable products, $8 \%$ optionally mentioned organic. This proportion is quite similar to the overall share of organic produce sold in Denmark. It is therefore likely to assume that the respondents resemble the average Danish consumers. Consumption of organic food products is still increasing in Denmark and it is estimated that the share of consumers who buy organic food products increased from 4\% in 2006 to $7 \%$ in $2009^{46}$.

In both the 'Dogma' and the Agricultural Fair survey, the respondents declare to have a preference for local produce. As described above, the 'Dogma' consumers deliberately chose a box where the products are locally or nationally produced and the preference from this group was therefore expected. The Agricultural Fair consumers also expressed a preference for local products. Yet, when put into context with relations on appearance, country of origin, price and shelf life, the local parameter was only selected by $40 \%$ of the respondents. In this situation the respondents might think of themselves as shoppers in a supermarket. However, local produce is at present not widely available in Danish supermarkets and is therefore not an optional parameter to look for. The consumers might have the preference for local products but they primarily shop in supermarkets where the produce is not available. Whether $40 \%$ of the respondents who prefer 'local' actively seek out local products from farm shops and local markets when possible, or have thought of the display of local products at the Roskilde Agricultural Fair when responding, is another question.

\section{Exploring consumers' views on seed source and 'organic' issues}

While many consumers have heard of the term 'organic' and are aware of one of its central features - namely that it is chemical free-most are unfamiliar with organic farming standards and practices ${ }^{12,47}$. The literature suggests some consumer knowledge and awareness of what the term organic means; yet, consumers (sometimes within the same country) are not consistent in their interpretation of what is $\operatorname{organic}^{48}$. This is illustrated in the 'Agricultural Fair' questionnaire as $53 \%$ assumed that all organic vegetables products originate from organically produced seeds. This is the logical answer that comes into mind. Yet, one must suspect than unfamiliarity with the subject caused this result. Compared to other questions in the questionnaire this was the question where the largest fraction of respondents answered 'do not know'. This could be an indicator of real confusion, as they probably anticipate that seeds used in organic farming are of organic origin, and to some extent lack of knowledge of the organic standards and rules governing organic farming. To maintain integrity in the organic supply chain it is therefore important to highlight these areas to the consumers. As stated earlier, there continues to be difficulties for seed producers in equivalent production of organic and non-organic seeds of the same variety $^{32}$. This leads to organic production of somewhat older varieties, meaning that many of the best new varieties do not reach the organic growers at the same speed as they reach the conventional growers ${ }^{29}$. Denmark has made considerable efforts to meet the demands from the European Union when it comes to producing organic seed for organic agriculture. The Danish seed companies have been involved in practical production; yet, the demands were not quite as expected. Possibly because the cultivars produced were not in demand by the vegetable producers or because too large quantities were produced. Some organic producers apparently try to avoid organic seeds because of, e.g., high costs. Therefore, the Danish production, at present, is limited. 
Table 3. 'Agricultural Fair' consumers' $(N=112)$ response $(\%)$ to how frequently they use babyleaf products in their households.

\begin{tabular}{lcccc}
\hline Question & $\begin{array}{c}\text { Several } \\
\text { times } \\
\text { a week }\end{array}$ & $\begin{array}{c}\text { Once } \\
\text { a week }\end{array}$ & $\begin{array}{c}\text { Once in } \\
\text { a while }\end{array}$ & Never \\
\hline $\begin{array}{l}\text { How often do you use } \\
\text { babyleaf products in } \\
\text { your household? }\end{array}$ & $36 \%$ & $17 \%$ & $43 \%$ & $4 \%$ \\
\hline
\end{tabular}

In organic babyleaf production seed source is an even more significant issue to consider. It could be argued that the 'in it for the profit' producers using mainly conventional seeds could damage the organic labeling if this is of high priority to the organic consumers. On the other hand, the producers with preference for organic seeds could use it as a brand, generating a surplus on the product. Hughner et al. ${ }^{49}$ synthesized the findings of published research on organic food consumption and found environmental concern to be a factor in consumers' attitudes toward organic food. Yet, this is not a driving factor of organic purchase. Perceptions of good health, nutritional benefits and taste are more important in the purchase of organic food ${ }^{50}$.

\section{Innovations in the babyleaf chain}

The global food system can supply foods from different sources at any time of the year ${ }^{51}$. This ensures the consistency in food variety and quality for consumers around the world. Further, since fresh produce plays a critical role in the competitive strategy of retailers, year round availability is regarded as necessary. Yet, these very real benefits to consumers are associated with several unpaid costs. Shipping or trucking costs are passed on to the consumers; unpriced, environmental costs are not. The chains originating in the southern parts of Europe are very strong and due to favorable climate they can provide babyleaf produce to the rest of Europe on a year round basis. Slowly they are beginning to enter the organic market and increase this production in line with the demand from the retailers. No doubt they consider this a profitable niche.

The short food supply chain, as described in the case of Aarstiderne.com, provides an alternative to the global food system. It is significant to acknowledge that there are current alternative interests among consumers than those related to highly specialized and industrialized supply chains ${ }^{12}$. Many consumers favor, for example, organic products and/or local products. Alternative short food supply networks might not be directly applicable for babyleaf production due to the highly perishable nature of the products. Yet, Aarstiderne.com has succeeded with the production and to introduce a babyleaf product to 'Dogma' consumers 'out of peak season' was much welcomed. In this alternative babyleaf chain, feedback loops from consumers are provided for the whole chain through consumer interaction on the company webpage, e-mail communication and company presence on blogs and through frequent questionnaires such as the one presented here. This direct link between company and consumers ensures that the right amount and type of vegetables enter the boxes.

The two groups of respondents, the 'Agricultural Fair' and the 'Dogma' consumers, both cover consumers who have an interest in babyleaf produce and they are therefore relevant to include in a chain perspective. They have the potential to point at preferences and interests in quality properties that could be a driving force for product development and innovation in a chain perspective. Feedback loops from the consumers to other actors in the chain are very important in order to develop and produce new babyleaf products that maintain these consumers' interest in the produce.

\section{Conclusions and Perspectives}

The overall conclusion from the two questionnaires is the genuine interest of Danish consumers in babyleaf products. The consumers would like more products, and therefore new niches within seed production could be given priority among seed producers and the babyleaf chain. Judging from consumer interest in babyleaf products there is plenty of room for innovation processes of new seeds and products in the babyleaf chain.

It seems as though the main drivers of the babyleaf chain originate in southern Europe as they are geared to exploit their competitive advantages linked to good-quality, wellfunctioning cold chains and potentials for year round supply of babyleaf products. Some consumers favor and expect products of local origin; yet, at present, they seek these options outside the supermarket chains. For organic produce there are Danish producers who favor a closed organic cycle from 'seed to end product' and there might be potentials for this as a signaling value in the chain that can be used to differentiate products on 'quality' parameters.

As positive environmental and health aspects associated with babyleaf products are put forward by various authors ${ }^{39-41}$ it could be relevant to look further into these factors and products in general. Both environmental and health aspects might make consumption increase even further. It is therefore essential to focus on seed production of new types of vegetables suited for babyleaf production and, just as important, seeds for a complementary organic production. The seeds and quality of the seeds play an important role in babyleaf production and should be viewed as, not just a raw material in the chain, but as the initial step in the vegetable production chain. It is the seed that determines the characteristics of the products and constant breeding efforts are mobilized to produce the products in demand by the babyleaf industry and consumers. Dialog between the actors in the babyleaf chain is therefore essential for the breeders to meet the consumer demands from both a conventional and an organic farming perspective. 
More than ten times the amount of seeds used for a bunched spinach product is used in babyspinach production ${ }^{4}$. Not all types of seeds are readily available for babyleaf production and new niches cannot develop before the seeds are produced.

When it comes to organic seed, the spiral so far has been negative as there are no incentives for many producers in the organic chain to use organic seed exclusively. It is therefore an uncertain business for seed companies to produce organic seed as long as organic vegetable growers can continue to claim first priority to varieties for which no organic seed is available. Questions to put forward in the supply chains might therefore involve: What cultivars do the producers want and in which quantities? Consequently, it will be a crucial element to ensure feedback loops from the vegetable producers and the market as a whole to the seed producers. At the same time, it is necessary to make retailers take steps to require that organic seeds are used in babyleaf products, as the babyleaf producers seem to favor nonorganic seeds because this allows a higher profit for organic babyleaf producers. The producers of seeds for babyleaf production cannot drive such a development without cooperation with other actors in the supply chain. It is important to focus on organic seed to secure one of the organic principles-self-reliance, and at the same time close the organic circle from start (seed) to end (product). Integrity should be the driving force that makes the whole supply chain responsible for producing the right type of organic seeds in the right amount. Lack of commitment from the producer's side might, in the long run, jeopardize the organic reputation and brand of different leafy vegetable products.

Acknowledgements. This research was funded by the Region of Zealand through the Technology Centre Seedland. We thank colleagues from Roskilde University and Aarhus University for feedback on the manuscript, in particular Erling Jelsøe and Bente Kjærgaard, and Aarstiderne.com for their willingness to participate in this research.

\section{References}

1 Deleuran, L.C. 2010. Seed quality in a value chain perspective. The case of babyleaf products. $\mathrm{PhD}$ thesis, Roskilde University.

2 Deleuran, L.C. and Boelt, B. 2006. Spinach seed production in Denmark. International Spinach Conference, La Conner, Washington, DC p. 13-15.

3 Jarosz, L. 2008. The city in the country: Growing alternative food networks in the Metropolitan areas. Journal of Rural Studies 24:231-244.

4 De Rosa, A. 2004. Spinacio. II Divulgatore n1/2004. Ortaggi da foglia, p. 60-66.

5 Opera, L.U. and Mazaud, F. 2001. Food traceability from field to plate. Outlook on Agriculture 30:239-247.

6 Nicola, S., Fontana, E., Torassa, C., and Hoeberechts, J. 2006. Fresh-cut produce: postharvest critical issues. Acta Horticulturae 712:223-230.

7 NYSERDA. 2008. Energy investments and $\mathrm{CO}_{2}$ emissions for fresh produce imported into New York State compared to the same crops grown locally. Final report. Available at Web site http://www.nyserda.org/publications/locally\%20grown\% 20imported\%20produce.pdf (verified September 14, 2010).

8 Faostat. 2010. Available at Web site http://faostat.fao.org/site/ 342/default.aspx (verified September 14, 2010).

9 Nucci, M.L., Cuite, C.L., and Hallmann, W.K. 2009. When good food goes bad: Television network news and the spinach recall of 2006. Science Communication 31:238-265.

10 Buckley, M., Cowan, C., McCarthy, M., and O'Sullivan, C. 2005. The convenience consumer and food-related lifestyles in Great Britain. Journal of Food Products Marketing 11:3-25.

11 Carrigan, M., Szmigin, I., and Leek, S. 2006. Managing routine food choices in UK families: The role of convenience consumption. Appetite 47:372-383.

12 O'Doherty Jensen, K., Lund, T.B., Andersen, L.M., Christensen, V.T., Krarup, S., Christensen, T., Denver, S., Bossen, H., Hindbrog, H., Roland, T., and Øllegaard, G. 2008. Hvorfor køber forbrugerne økologi? In H.F. Alrøe and N. Halberg (eds). Udvikling, vækst og integritet i den danske $\emptyset$ kologisektor. ICROFS, Tjele, Denmark.

13 Taylor, A.G. 1997. Seed storage, germination and quality. In H.C. Wein (ed.). The Physiology of Vegetable Crops. CAB International, Wallingford, UK.

14 Morris, C. and Young, C. 2000. 'Seed to shelf', 'teat to table', 'barley to bear' and 'womb to tomb': discourses of food quality and quality assurance schemes in the UK. Journal of Rural Studies 16:103-115.

15 Marsden, T.K. 1998. New rural territories: regulating the differentiated rural spaces. Journal of Rural Studies 14: 107-117.

16 Kottila, M. and Rönni, P. 2008. Collaboration and trust in two organic food chains. British Food Journal 110:376-394.

17 Feller, A., Shunk, D., and Callerman, T. 2006. Value chains versus supply chains. BPT Trends, March 2006. Available at Web site http://www.ceibs.edu/knowledge/papers/images/ 20060317/2847.pdf. (verified September 22, 2010).

18 Nielsen, R.N. 2008. Feeding food producers with (Regional) knowledge for innovation? Working Paper Series. Department of Business Studies No. 13. Aalborg University, Denmark. Available at Web site http://www.business.aau.dk/wp/08-13. pdf (verified October 25, 2010).

19 Baker, D. 2003. The Danish food marketing chain: developments and policy choises. Report 154. Danish Research Institute of Food Economics. Available at Web site http://www. foi.life.ku.dk/Publikationer/FOI_serier/ /media/migration $\%$ 20folder/upload/foi/docs/publikationer/rapporter/nummererede $\%$ 20rapporter/150-159/154.pdf.ashx (verified October 25, 2010).

20 Weiming, H., Pangyuan, L., Baohai, Z., and Shufang, Z. 2008. A new kind of no-polluted cultivation of vegetables. The cultivation of baby salad leaves. In Vegetable Production, Quality and Process Standardization in Chain: a Worldwide Perspective. Vege 2008 Beijing, October 14-17, 2008. Beijing, China.

21 Lucier, G., Allshouse, J., and Biing-Hwan, L. 2004. Factors affecting spinach consumption in the United States. Electronic Outlook report from the Economic Research Service. Available from Web site http://www.ers.usda.gov/publications/ VGS/jan04/vgs30001/vgs30001.pdf (verified September 14, 2010).

22 Morelock, T. and Correll, J. 2007. Spinach. In J. Prohens and F. Nuez (eds). Handbook of Plant Breeding. Springer, New York, p. 189-218. 
23 USDA. 2005. U.S. Department of Agriculture, Agricultural Research Service. USDA National Nutrient Database for Standard Reference, Release 18.

24 Conte, A., Conversa, G., Scrocco, C., Brescia, I., Laverse, J., Alia, A., and Del Nobile, M.A. 2008. Influence of growing periods on the quality of baby spinach leaves at harvest and during storage as minimally processed produce. Postharvest Biology and Technology 50:190-196.

25 Lestrange, M., Koike, S., Valencia J., and Chaney, W. 2010 (online publication). Spinach production in California. University of California, Division of Agriculture and Natural Resources. Publication 7212. Available at Web site http://ucanr. org/freepubs/docs/7212.pdf (verified September 14, 2010).

26 Renting, H., Marsden, T.K., and Banks, J. 2003. Understanding alternative food networks: exploring the role of short food supply chains in rural development. Environment and Planning A 35:393-411.

27 Marsden, T., Banks, J., and Bristow, G. 2000. Food supply chain approaches: exploring their role in rural development. Sociologia Ruralis 40:424-438.

28 Lammerts van Bueren, E.T. and Verhoog, H. 2006. Organic plant breeding and seed production: ecological and ethical aspects. In P. Kristiansen, A. Taji and J. Reganold (eds). Organic Agriculture. A Global Perspective. CABI, Wallingford, UK, p. 123-139.

29 Defra. 2009. UK Annual Derogation Report for 2008. Prepared by: The Soil Association on behalf of Defra, January 2009. Available at Web site http://pdir.fvm.dk/Rapporter_ fra_2008.aspx ?ID=11865 (verified September 14, 2010).

30 SKAL. 2009. 2008 seed report. The Netherlands. Available at Web site http://pdir.fvm.dk/Rapporter_fra_2008.aspx?ID= 11865 (verified September 14, 2010).

31 The Danish Plant Directorate. 2009. Rapport for 2008 om danske tilladelser til anvendelse af ikke- $\varnothing$ kologisk frø, læggekartofler og andet vegetativt formeringsmateriale I den $\varnothing$ kologiske produktionsmetode. Available at Web site http:// pdir.fvm.dk/Rapporter_fra_2008.aspx?ID=11865 (verified September 14, 2010).

32 Deleuran, L.C. and Boelt, B. 2010. Organic leek seed production - securing seed quality. Acta Horticulturae in press.

33 Peerenboom, R. 2004. Putting organic seed production in perspective. In Challenges and Opportunities for Organic Agriculture and the Seed Industry. Proceedings of the First World Conference on Organic Seed, Rome, Italy, p. 6-8.

34 Rubitschek, P. 2004. Use and availability if organic vegetable seed. In Challenges and Opportunities for Organic Agriculture and the Seed Industry. Proceedings of the First World Conference on Organic Seed, Rome, Italy, p. 59-61.

35 Lupton, D. 1996. Food, the Body and the Self. Sage, London.

36 Greenwood, M.R.C. and Gershwin, M.E. 2010. Foods for health: A roadmap for the future. Annals of the New York Academy of Sciences 1190:ix-x.
37 Grunert, K.G. 2010. European consumers' acceptance of funcitional foods. Annals of the New York Academy of Sciences 1190:166-173.

38 Franke, A.A., Custer, L.J., Arakaki, C., and Murphy, S.P. 2004. Vitamin C and flavonoid levels of fruit and vegetables consumed in Hawaii. Journal of Food Composition and Analysis 17:1-35.

39 Hossimotto, N.M.A., Genovese, M.I., and Lajolo, F.M. 2005. Antioxidant activity of dietary fruits, vegetables, and commercial frozen fruit pulps. Journal of Agricultural and Food Chemistry 53:2928-2935.

40 Martínez-Sánchez, A., Gil-Izquierdo, A., Gil, M.I., and Ferreres, F. 2008. A comparative study of flavonoid compounds, vitamin $\mathrm{C}$, and antioxidant properties of baby leaf Brassicaceae species. Journal of Agricultural and Food Chemistry 56:2330-2340.

41 Bogers, R.P. 2006. The future of horticultural science and education: A European perspective. Report from the BeNeLux Society for Horticultural Science. 2006 Symposium.

42 Salaün, Y. and Flores, K. 2001. Information quality: meeting the needs of the consumer. International Journal of Information Management 21:21-37.

43 Shewfelt, R.L. 2006. Defining and meeting consumer requirements. Acta Horticulturae 712:31-37.

44 Muramoto, J. 1999. Comparisons of nitrate content in leafy vegetables from organic and conventional farms in California. Report. Available at Web site http://www.agroecology.org/ documents/Joji/leafnitrate.pdf (verified September 14, 2010).

45 Black, J. 2009. The CSA that isn't one. Available at Web site http://www.gourmet.com/foodpolitics/2009/01/danish-csas (verified September 14, 2010).

46 Denmarks Statistics. 2009. Available at Website http:// www.dst.dk/pukora/epub/Nyt/2010/NR191.pdf (verified September 14, 2010).

47 Harper, G.C. and Makatouni, A. 2002. Consumer perception of organic food production and farm animal welfare. British Food Journal 104:287-299.

48 Yiridoe, E.K., Bonti-Ankomah, S., and Martin, R.C. 2005. Comparison of consumer perceptions and preference toward organic versus conventionally produced foods: A review and update of the literature. Renewable Agriculture and Food Systems 20:193-205.

49 Hughner, R.S., McDonagh, P., Prothero, A., Shultz, C.J. II, and Stanton, J. 2007. Who are organic food consumers? A compilation and review of why people purchase organic food. Journal of Consumer Behavior 6:94-110.

50 Makatouni, A. 2001. What motivates consumers to buy organic food in the UK. Results from a qualitative study. British Food Journal 104(3/4/5):345-352.

51 Wilkins, J.L. 1996. Seasonality, food origin, and food preference: a comparison between food cooperative members and nonmembers. Journal of Nutrition Education 28:329-337. 